Шуляк П. І., к.військ.н., с.н.с.;

Колодін О. М.

Центральний науково-дослідний інститут Збройних Сил України, Київ

\title{
Тенденції розвитку військово-морських сил країн-сусідів України за Чорноморським регіоном
}

Резюме. У статті розглядаються тенденції розвитку та переоснащення бойового корабельного складу військово-морських сил країн-сусідів України, що мають доступ до акваторії Чорного моря.

Ключові слова: тенденції розвитку; військово-морські сили; суміжні країни; корабельний склад.

Постановка проблеми у загальному вигляді. Протягом останнього десятиріччя відбулися події, які безпосередньо торкнулися країн Чорноморського регіону. Членство Болгарії та Румунії у Північноатлантичному альянсі (НАТО), грузино-російський конфлікт, незаконна анексія Кримського півострова Російською Федерацією (РФ) та зміни політичних векторів частини держав призвели до певних зміщень у балансі сил у регіоні.

Військово-політичні інтереси всіх зазначених країн безпосередньо перетинаються в акваторії Чорного моря, а їх військово-морські сили (ВМС) становлять важливу частину збройних сил. Саме тому аналіз планів розвитку цього виду збройних сил країн зазначеного регіону може відображати їх інтереси та наміри на перспективу.

Найінформативнішим показником перспектив розвитку ВMC $\epsilon$ процес переоснащення бойового корабельного складу, який безпосередньо впливає на ефективність цього виду збройних сил.

Аналіз останніх досліджень i публікацій. Головна інформація щодо перспектив переоснащення 3'єднань ВMC, країн Чорноморського регіону міститься у керівних документах цих країн.

Для Туреччини це "Перспективний план оборонної розбудови до 2020 - 2025 років”[1]; "Десятирічна програма закупівель і поставок до 2025 року" [2]. Крім того, технічне переозброєння 3С Туреччини здійснюється в рамках виконання "Плану модернізації ЗС Туреччини на період до 2025 року”[3].

Реформування флоту РФ відбувається відповідно до положень "Концепції будівництва і розвитку Збройних сил РФ на період до 2020 року" [4], Воєнної доктрини РФ [5], програми "Перспективний флот" на період 2016-2025 років" [6], пакета законодавчих актів "Про параметри основного бойового складу ЗС РФ до 2020 року" та “Державної програми озброєнь РФ на 2018 - 2027 роки” [7].

Процес реформування ЗС Болгарії регламентовано “Довгостроковою програмою розвитку військ та сил до 2020 року” [8].

Реформування морських сил Румунії здійснюється на підставі "Національної оборонної стратегії Румуніі” [9] та "Стратегії трансформації ЗС Румунії на період до 2025 року" [10].

Хоча керівні документи i містять інформацію щодо планів 3 переозброєння збройних сил конкретних країн, вони не відображають загальну динаміку розвитку ВМС регіону, тому існує необхідність в узагальненні такої інформації для відстеження глобальних процесів розвитку ВMC та складання прогнозів воєнно-політичної обстановки в регіоні.

Метою статті $є$ узагальнення інформації щодо технічного переоснащення корабельного складу ВМС країн Чорноморського регіону, визначення тенденцій розвитку ВMC та формування рекомендацій щодо шляхів їх використання.

Виклад основного матеріалу. Відповідно до “Державної програми озброєнь РФ на 2018 - 2027 роки” основними видами OВТ для потреб ЧФ ЗС РФ визначені:

сторожові кораблі проекту $11356 \mathrm{P}$ призначені для знищення надводних кораблів і суден, підводних човнів і наземних об'єктів противника, дозорної служби, патрулювання, охорони морських комунікацій;

багатоцільові дизель-електричні підводні човни проекту 636.3 "Варшавянка” - призначені для упереджувального виявлення та знищення кораблів противника;

багатоцільові малі ракетні кораблі проекту 21631 "Буян-М" - призначені для охорони та захисту економічної зони держави; 
патрульні кораблі відкритого моря охорони кораблів та суден на морських шляхах, проекту 22160 "Василій Биков" - призначені для несення прикордонно-патрульної служби, попередження контрабандної та піратської діяльності, пошуку та надання допомоги постраждалим, екологічного моніторингу, охорони баз та водних районів.

Порівняльні кількісні показники корабельного складу ЧФ РФ до та після проведення заходів 3 оновлення корабельного складу наведено у вигляді діаграми на рис. 1 та у табл. 1.

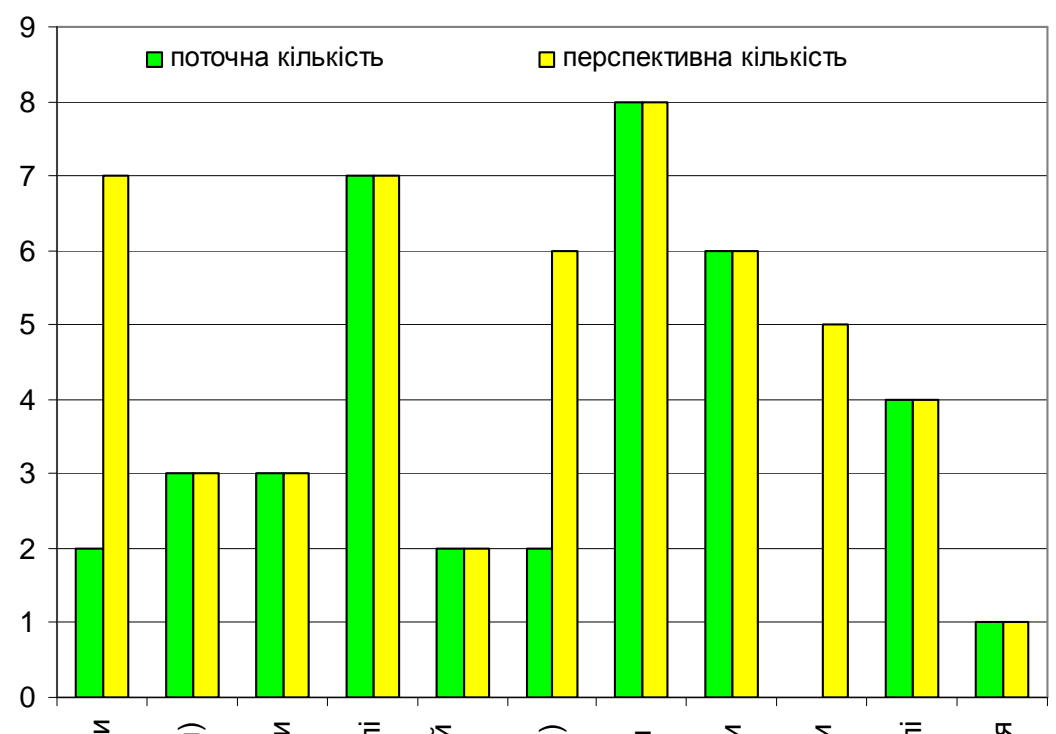

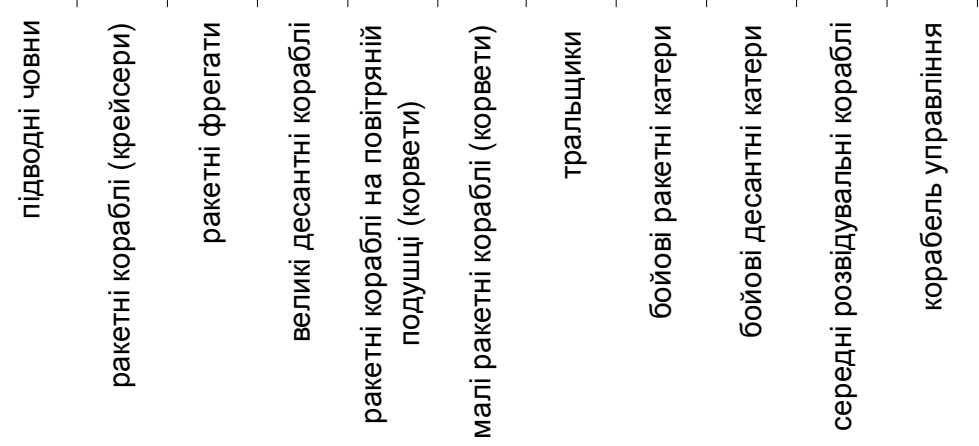

Рис. 1. Порівняні значення показників поточної та перспективної кількості кораблів ЧФ РФ

Таблиця 1

Кількісні показники корабельного складу ЧФ РФ

\begin{tabular}{|l|c|c|}
\hline \multicolumn{1}{|c|}{ Найменування } & $\begin{array}{c}\text { поточна } \\
\text { кількість }\end{array}$ & $\begin{array}{c}\text { перспективна } \\
\text { кількість }\end{array}$ \\
\hline підводні човни & 2 & 7 \\
\hline ракетні кораблі (крейсери) & 3 & 3 \\
\hline ракетні фрегати & 3 & 3 \\
\hline великі десантні кораблі & 7 & 7 \\
\hline ракетні кораблі на повітряній подушці (корвети) & 2 & 2 \\
\hline малі ракетні кораблі (корвети) & 2 & 6 \\
\hline тральщики & 8 & 8 \\
\hline бойові ракетні катери & 6 & 6 \\
\hline бойові десантні катери & 0 & 5 \\
\hline середні розвідувальні кораблі & 4 & 4 \\
\hline корабель управління & 1 & 1 \\
\hline
\end{tabular}

Після анексії Кримського півострова РФ керівництвом ЗС було прийнято рішення щодо переозброєння та оновлення корабельного складу ЧФ. Однак у зв'язку із загостренням обстановки на Західному (Балтійському) стратегічному напрямку (нарощення сил НАТО) РФ намагається створити потужну систему оборони на
Північному (Арктичному) та Західному (Балтійському) стратегічних напрямках. Через нестачу фінансування та вплив міжнародних санкцій переозброєння корабельного складу ЧФ проводиться з від термінуванням [11].

Натомість нарощення кількості підводних човнів та сторожових кораблів свідчить про прагнення РФ зберегти паритет сил в акваторії 
Чорного моря 3 одночасною можливістю стримування великого угруповання морських сил ворога. Створення групи десантних катерів надасть змогу швидкого реагування та можливість підтримки операцій на суходолі.

Основними напрямами реформування та розвитку ВМС Туреччини є оновлення корабельного складу, зокрема за рахунок збільшення кількості корветів, патрульних катерів та танкодесантних плаваючих засобів; посилення потенціалу та можливостей флоту 3 маневрування, протимінної, протичовнової, протиповітряної оборони; забезпечення ефективного контролю надводної обстановки; оновлення арсеналу боєприпасів (придбання протикорабельних ракет).

До оновлення корабельного складу ВМС Туреччини належать такі заходи:

програма будівництва підводних човнів проекту 214TH, які мають протикорабельну спеціалізацію;

програма будівництва корветів типу “Ада", призначених для пошуково- рятувальних операцій, патрулювання та боротьби з підводними човнами противника;

програма будівництва багатоцільових фрегатів типу “ТF-2000”, призначених для розвідувальної діяльності, спостереження, ідентифікації цілей, завчасного попередження, боротьби 3 підводними човнами, надводними кораблями та ведення протиповітряної оборони; програма проектування та будівництва десантного корабля-дока (LPD), укомплектованого десантними кораблями на повітряній подушці;

програма закупівлі двох фрегатів типу “О.Х.Перрі”, призначених для протичовнового захисту та протиповітряної оборони транспортних конвоїв, амфібійних з'єднань та протичовнових груп.

Порівняльні кількісні показники корабельного складу ВМС Туреччини до та після проведення заходів 3 оновлення корабельного складу наведено у вигляді діаграми на рис. 2 та у табл. 2.

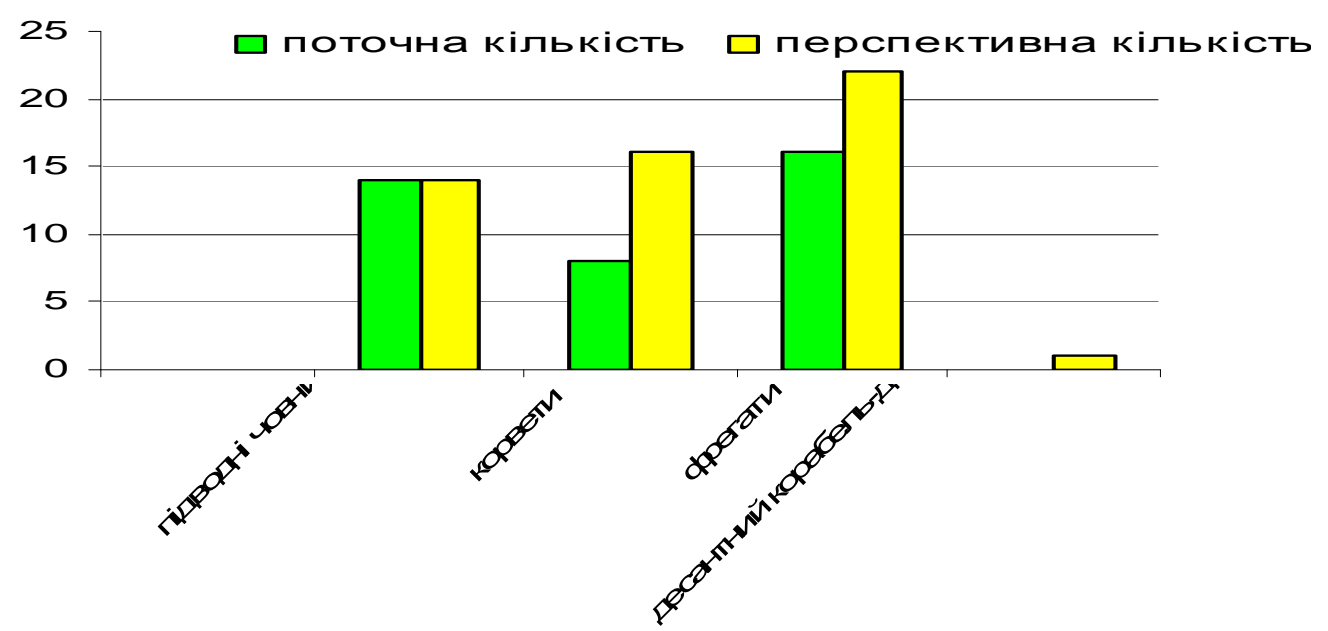

Рис. 2. Порівняні значення показників поточної та перспективної кількості кораблів ВМС Туреччини

Таблиця 2

Кількісні показники корабельного складу ВМС Туреччини

\begin{tabular}{|l|l|c|}
\hline Найменування & $\begin{array}{l}\text { Поточна } \\
\text { кількість }\end{array}$ & $\begin{array}{c}\text { Перспект. } \\
\text { кількість }\end{array}$ \\
\hline підводні човни & 14 & 14 \\
\hline корвети & 8 & 16 \\
\hline фрегати & 16 & 22 \\
\hline десантний корабель-док & 0 & 1 \\
\hline
\end{tabular}

Кардинальне оновлення корабельного складу військово-морських сил Туреччини здебільшого спрямовано на оборонні цілі (майже весь корабельний склад, що оновлюється та модернізується, призначений для боротьби 3 підводними човнами та кораблями противника). Виключенням $\epsilon$ десантний корабель-док, призначений для підтримки наземних операцій з моря.
В умовах обмеженого фінансування військово-політичне керівництво Болгарії продовжує виконання "Довгострокової програми розвитку військ та сил до 2020 року”. Виконуються заходи 3 приведення 3'єднань i частин національних ВMC відповідно до стандартів НАТО та ЕС.

До програми реформування військовоморських сил, зокрема, належить закупівля у французької компанії “DCNS" модульних корветів типу "ГоВінд", призначених для забезпечення морської безпеки та боротьби 3 піратством. Порівняльні кількісні показники корабельного складу ВМС Болгарії до та після проведення заходів 3 оновлення корабельного складу наведено у вигляді діаграми на рис. 3 та у табл. 3 . 


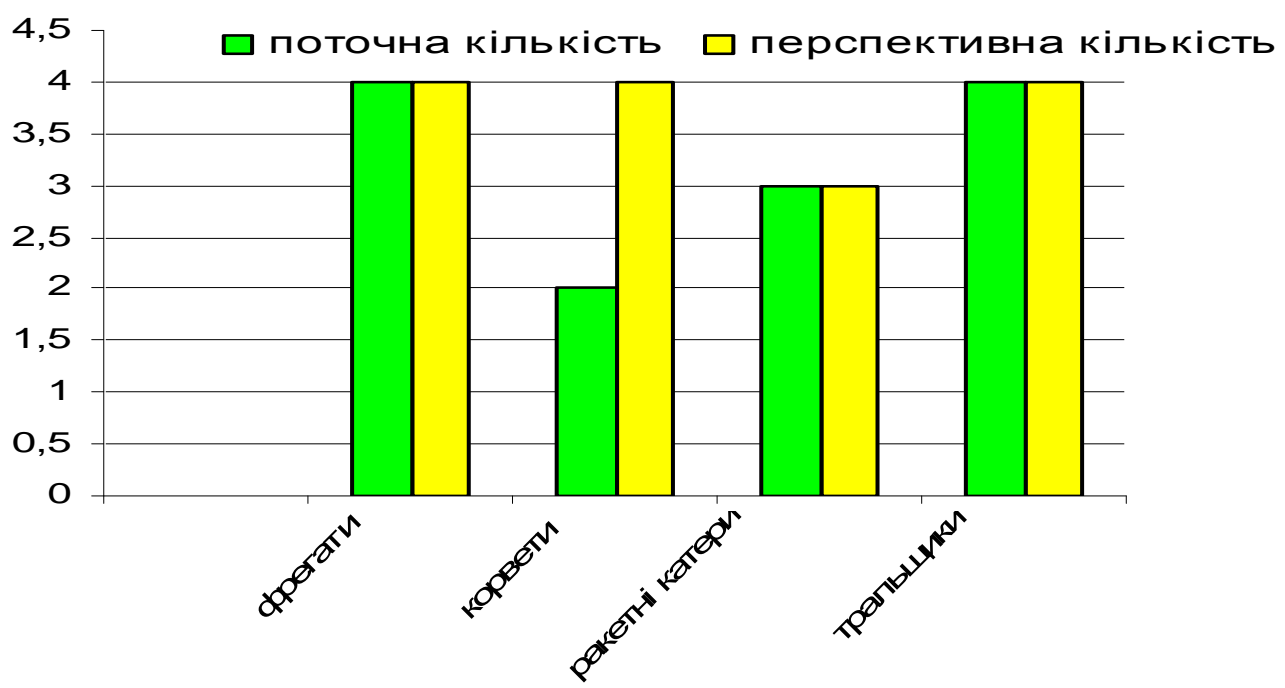

Рис. 3. Порівняні значення показників поточної та перспективної кількості кораблів ВМС Болгарії

Таблиця 3

Кількісні показники корабельного складу ВМС Болгарії

\begin{tabular}{|l|c|c|}
\hline Найменування & $\begin{array}{c}\text { Поточна } \\
\text { кількість }\end{array}$ & $\begin{array}{c}\text { Перспективна } \\
\text { кількість }\end{array}$ \\
\hline Фрегати & 4 & 4 \\
\hline Корвети & 2 & 4 \\
\hline Ракетні катери & 3 & 3 \\
\hline Тральщики & 4 & 4 \\
\hline
\end{tabular}

У морських силах Румунії виконуються заходи 3 приведення 3'єднань і частин відповідно до стандартів НАТО та ЄС.

Стратегія реформування МС Румунії передбачає модернізацію фрегатів типу 22 , які призначені для протикорабельної боротьби.

Порівняльні кількісні показники корабельного складу ВМС Румунії до та після проведення заходів з оновлення корабельного складу наведено у вигляді діаграми на рис. 4 та у табл. 4.

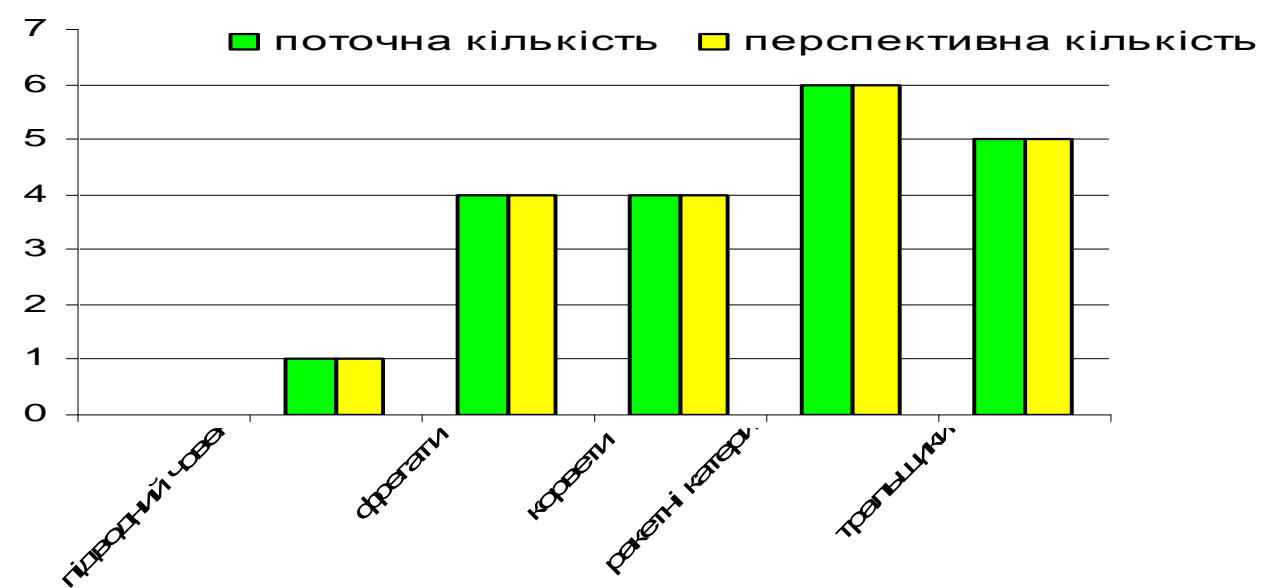

Рис. 4. Порівняні значення показників поточної та перспективної кількості кораблів ВМС Румунії

Таблиця 4

Кількісні показники корабельного складу ВМС Румунії

\begin{tabular}{|l|c|c|}
\hline Найменування & $\begin{array}{c}\text { Поточна } \\
\text { кількість }\end{array}$ & $\begin{array}{c}\text { Перспективна } \\
\text { кількість }\end{array}$ \\
\hline Підводний човен & 1 & 1 \\
\hline Фрегати & 4 & 4 \\
\hline Корвети & 4 & 4 \\
\hline Ракетні катери & 6 & 6 \\
\hline Тральщики & 5 & 5 \\
\hline
\end{tabular}

3 приводу реформування військовоморських сил Болгарії та Румунії, то через нестачу фінансування воно відбувається здебільшого за рахунок модернізації наявних кораблів, які зможуть виконувати завдання в будь-яких районах Світового океану, зокрема у складі міжнародних сил. Продовжуються також заходи 3 приведення у відповідність військово-морських сил до стандартів НАТО та $€ C$. 
Після грузино-російського конфлікту 2008 року частини (3'єднання) Сил морської охорони Грузії були розформовані та включені до складу Департаменту охорони державного кордону Міністерства внутрішніх справ Грузії. Власна програма розвитку відсутня. У розвитку департаменту БОХР активну участь беруть США, які керують плануванням, розробляють відповідні документи та фінансують проекти [11].

$$
\text { Кількісні показники поточного }
$$
корабельного складу БОХР Грузії наведено у табл. 5.
Таблиця 5

Кількісні показники корабельного складу БОХР Грузії

\begin{tabular}{|l|c|}
\hline \multicolumn{1}{|c|}{ Найменування } & Поточна кількість \\
\hline Бойових кораблів & 2 \\
\hline Бойових катерів & 37 \\
\hline Сторожових катерів & 5 \\
\hline Десантних катерів & 2 \\
\hline Патрульних катерів & 30 \\
\hline
\end{tabular}

Узагальнені кількісні показники поточного та перспективного корабельного складу країн-сусідів України за Чорноморським регіоном наведено на рис. 5 .

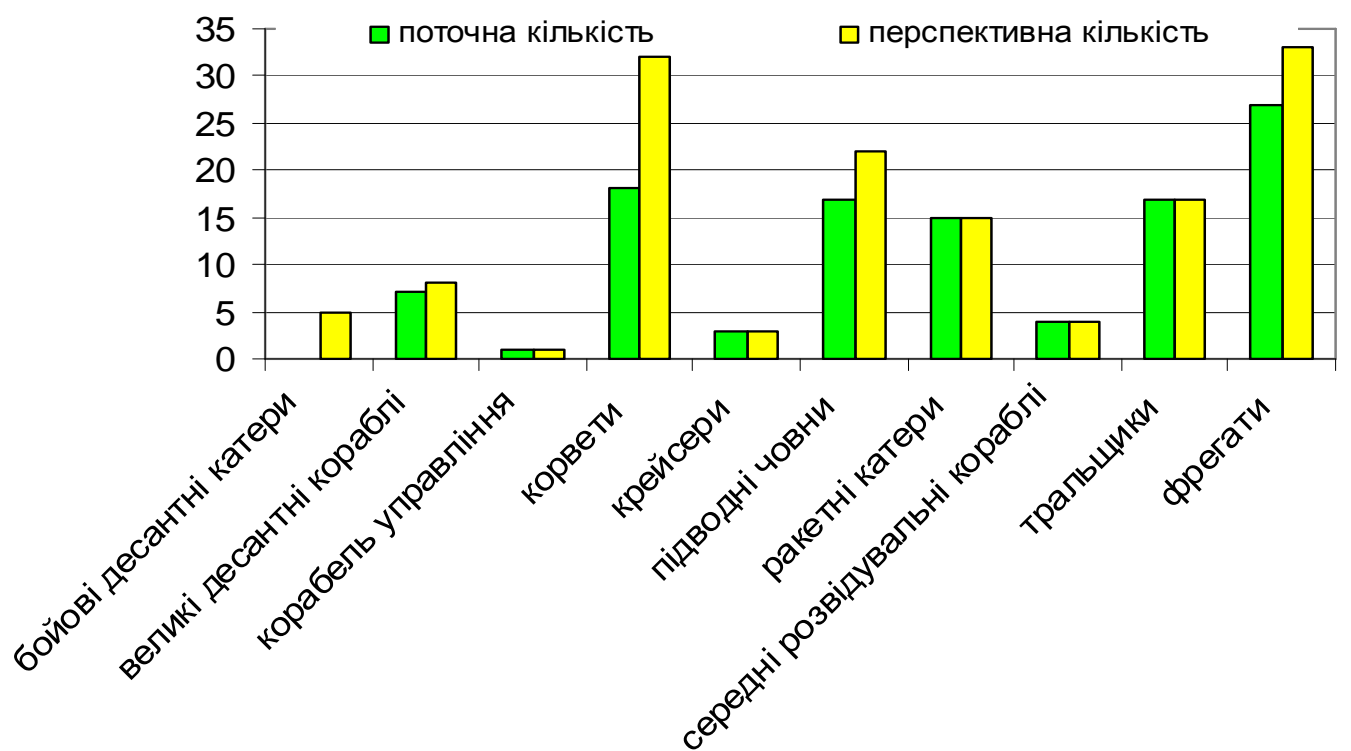

Рис. 5. Узагальнені кількісні показники поточного та перспективного корабельного складу країн-сусідів України за Чорноморським регіоном

Загальними тенденціями у переоснащенні військово-морських сил країн Чорноморського регіону $\epsilon$ переважання універсальної спеціалізації модернізованих i нових кораблів над кораблями вузької спеціалізації, спрямованість на ведення розвідки і спостереження, охоронні та сторожові функції, а також прикордонні функції, зокрема, боротьба з контрабандою та проявами піратства.

Висновки та перспективи подальших досліджень. У статті узагальнено програми оновлення корабельного складу військовоморських сил країн Чорноморського регіону. Визначено загальні тенденції переоснащення корабельного складу ВМС. Отримані результати надалі використовуватимуться для визначення загального потенціалу збройних сил країн Чорноморського регіону та прогнозування можливих шляхів розвитку воєнно-політичної ситуації у Чорноморському регіоні.

\section{СПИСОК ВИКОРИСТАНОЇ ЛІТЕРАТУРИ}

1. Перспективний план оборонної розбудови до 2020-2025 pp. URL: http://www.msb.gov.tr (дата звернення 02.07.2018).

2. Десятирічна програма закупівель i поставок до 2025 року. URL: http://www.msb.gov.tr (дата звернення 02.07.2018).

3. План модернізації 3С Туреччини на період до 2025 року. URL: http://www.msb.gov.tr (дата звернення 02.07.2018).

4. Концепция строительства и развития Вооруженных сил Российской Федерации на период до 2020 года. URL: http://www.kremlin.ru/ (дата звернення 02.07.2018).

5. Военная доктрина Российской Федерации. URL: http://static. kremlin.ru/media/events/files/ 41d527556bec8deb3530.pdf (дата звернення 02.07.2018).

6. Перспективний флот. URL: https://doc.mil.ru/ documents (дата звернення 02.07.2018).

7. Государственная программа вооружений 2027. URL: http:// intersectionproject.eu/ru/article /security/gosudarstvennaya-programma-vooruzheniy2027 (дата звернення 02.07.2018). 
8. Довгострокова програма розвитку військ Public/DetaliiDocument/182367 та сил до 2020 року". URL: https://www.mod.bg /bg/documents.html (дата звернення 02.07.2018).

\section{URL:}

9. Національна оборонна стратегія Румунії.

http://www.presidency.ro/files/userfiles/Strategia_Natio nala_de_Aparare_a_Tarii_1.pdf (дата звернення 02.07.2018).

10. Стратегіï трансформації 3С Румунії на період до 2025 року. URL: http://legislatie.just.ro/

\subsubsection{8).}

11. Перспективи

(дата звернення

переозброєння корабельного складу ВМС країн Чорноморського регіону. URL: https://navy.mil.gov.ua/perspektyvypereoz broyennya-korabelnogo-skladu-vms-krayinchornomorskogo-regionu/ (дата звернення 02.07.2018).

Стаття надійшла до редакції 10.08.2018

Шуляк П. И., к.воен.н., с.н.с.;

Колодін А. Н.

Центральный научно-исследовательский институт Вооруженных Сил Украины, Киев

Тенденции развития военно-морских сил стран-соседей Украины по Черноморскому региону

Аннотация. В статье рассматриваются тенденции развития и переоснащения боевого корабельного состава военно-морских сил стран-соседей Украины, которые имеют доступ к акватории Черного моря.

Ключевые слова: тенденции развития; военно-морские силы; соседние страны; корабельный состав.

\section{P. Shuljak, PhD (Military), senior researcher;}

\section{A. Kolodyn}

Central Research Institute of the Armed Forces of Ukraine, Kiev

Trends in the development of the naval forces of the neighboring countries of Ukraine in the Black Sea region

Resume. The article deals with the tendencies of development and re-equipment of the naval composition of the naval forces of the neighboring countries of Ukraine which have access to the Black Sea water area.

Keywords: trends in the development; naval forces; neighboring countries; shipbuilding. 